ISSN 1392-3196 / e-ISSN 2335-8947

Zemdirbyste-Agriculture, vol. 100, No. 4 (2013), p. 355-362

DOI 10.13080/z-a.2013.100.045

\title{
Energy balance of catch crops production
}

\author{
Pavel FUKSA, Josef HAKL, Václav BRANT \\ Czech University of Life Sciences Prague \\ Kamýcká 129, 16521 Praha 6, Suchdol, Czech Republic \\ E-mail: fuksa@af.czu.cz
}

\begin{abstract}
The aim of this paper was to evaluate catch crops for energy production and effectiveness in the areas with limited precipitation. Eight plant species: Brassica napus, Lolium multiflorum, Lolium perenne, Phacelia tanacetifolia, Raphanus sativus var. oleiformis, Sinapis alba, Trifolium incarnatum, Trifolium subterraneum, and un-seeded control were observed from 2005 to 2007 . Energy content of biomass (MJ kg-1) and energy production (GJ ha-1) of catch crops, volunteers and weeds were determined and energy balance (inputs, gain, and effectiveness) was calculated. Energy content of above-ground biomass of catch crops $\left(15.65-20.21 \mathrm{MJ} \mathrm{kg}^{-1}\right)$ was significantly $(P<$ 0.05 ) influenced by species and year. In average of 2005-2007, the total energy production was $18.19 \mathrm{GJ}^{-1}$ in un-seeded control (production of weeds and volunteers) and ranged from 24.74 to $57.02 \mathrm{GJ}^{-1}$ in the stands with evaluated catch crops. Catch crops represented $43-94 \%$ of the total energy production depending on plant species. Gain of positive energy balance of evaluated catch crops was influenced particularly by the year in relation to soil moisture by contrast to the un-seeded control. In all three years, positive energy balance was reached only by the stand with $S$. alba. P. tanacetifolia performed at the lowest value of additional energy and $R$. sativus performed at the highest energy accumulation in underground biomass.
\end{abstract}

Key words: calorific value, energy production, intercrop, volunteers, weed.

\section{Introduction}

Catch crops represent an important part of crop rotation in crop management and ecology. Catch crops have a positive effect on soil fertility, elimination of erosion, and on limiting nutrient loss. They are also very acceptable as breakers of crop rotations and can increase yields of the main crops (Joelsson, Kyllmar, 2002). Catch crops also contribute to weed control (Poggio, 2005; Rasmussen et al., 2006). Biomass production of catch crops is one of the main factors leading to stable circulation of organic matter in arable land. Input of organic matter to the soil is associated with the increase in soil fertility and soil aggregate stability (Brant et al., 2011).

In spite of the general advantages of the abovementioned catch crops, their growing should also bring energy profit in the agro-ecosystem in terms of energy input and output. This principle of energy balance is widely used for the evaluation of energy use efficiency (EUE), mainly for the comparison of different cropping systems (Alluvione et al., 2011; Moreno et al., 2011; Zentner et al., 2011), annual or perennial crops (e.g., Boehmel et al., 2008) or different crop species (Venturi, Venturi, 2003). In principle, energy balance comes from the comparison of inputs and outputs. Energy outputs are divided into energy of plant production, residue of plants, and irreversible energy loss. Input of energy consists of energy of the outer environment (sunlight, energy in soil, atmosphere and infrastructures of the surrounding environment), and energy of technological inputs, which consists of direct part (energy of human work, fossil energy, other energy sources - draught animal, etc.), and indirect part (energy of mechanisms, products of chemical industry, organic fertilizers, seeds, etc.) (Hülsbergen et al., 2001). Parameters most frequently used in considering EUE are net energy gain (difference between energy production and inputs of energy) and energy output/input ratio, which represents conversion of energy inputs into outputs (e.g., Venturi, Venturi, 2003; Angelini et al., 2005).

The previous research of energy balance was focused mainly on the evaluation of the most frequent field crops such as wheat, barley, sunflower, sorghum, winter rape, sugar beet (e.g., Venturi, Venturi, 2003; Moreno et al., 2011) or alternative energy crops such as industrial hemp (Prade et al., 2011) or giant reed (Angelini et al., 2005) usually under different crop management (e.g., Zentner et al., 2011). In spite of the wide range of published results, there is a lack of information about energy balance calculated for catch crops, mainly in terms of EUE and suitable species selection. Moreno et al. (2011) reported that effectiveness of energy input was strongly reduced in semi-arid environment, therefore it must be remembered, that environment, such as level of precipitation, could strongly influence EUE.

The aim of the research reported in this paper was: i) to compare a range of catch crops in terms of their 
energy production and effectiveness, ii) to determine which species of catch crops can produce significantly higher EUE as compared with the un-seeded control with only weeds and volunteers in the area with limited precipitation.

\section{Materials and methods}

Experimental locality. The experiment was established in Central Bohemia, Czech Republic in an experimental field station in Červený Újezd $\left(50^{\circ} 04^{\prime} 30^{\prime \prime}\right.$ $\mathrm{N}, 14^{\circ} 10^{\prime} 20^{\prime \prime} \mathrm{E}, 398 \mathrm{~m}$ a.s.1.). The long-term annual temperature is $7.9^{\circ} \mathrm{C}$ and precipitation $526 \mathrm{~mm}$. According to the latest climatic regionalization of the Czech Republic (Moravec, Votýpka, 2003), the locality falls into Class III, which is characterized by an average duration of the main vegetative period within the range of 160-177 days, the average annual total of precipitation below $580 \mathrm{~mm}$ and the rainless period of more than 22 days. Particle size distribution of the soil in the experimental site was in categories of soil particles $<0.01 \mathrm{~mm}, 0.01-0.05 \mathrm{~mm}$, $0.05-0.1 \mathrm{~mm}$ and $0.1-2 \mathrm{~mm}$ as follows $53.21 \%, 38.54 \%$, $2.32 \%$ and $5.93 \%$, respectively.

Experimental design. Eight plant species cultivated as catch crops: winter rape (Brassica napus L.) variety 'Bristol', seeding rate $-10 \mathrm{~kg} \mathrm{ha}^{-1}$, Italian ryegrass (Lolium multiflorum Lamk.) variety 'Lonar', $40 \mathrm{~kg} \mathrm{ha}^{-1}$, perennial ryegrass (Lolium perenne L.) variety 'Prolog', $20 \mathrm{~kg} \mathrm{ha}^{-1}$, phacelia (Phacelia tanacetifolia Benth.) variety 'Větrovská', $10 \mathrm{~kg} \mathrm{ha}^{-1}$, fodder radish (Raphanus sativus L. var. oleiformis Pers.) variety 'Ikarus', $25 \mathrm{~kg} \mathrm{ha}^{-1}$, white mustard (Sinapis alba L.) variety 'Veronika', $20 \mathrm{~kg} \mathrm{ha}^{-1}$, crimson clover (Trifolium incarnatum L.) variety 'Kardinál', $25 \mathrm{~kg} \mathrm{ha}^{-1}$, subterranean clover (Trifolium subterraneum L.) candivar, $30 \mathrm{~kg} \mathrm{ha}^{-1}$, and un-seeded control were observed from 2005 to 2007. The experiment was designed in random blocks. Each experimental treatment consisted of four plots (replicates) sized $30 \mathrm{~m}^{2}$ each $(3 \times$ $10 \mathrm{~m})$. The catch crop sowing followed the Triticum aestivum L. ('Alana') harvest (19 Aug. 2005, 24 Aug. 2006 and 13 Aug. 2007). Straw was chopped and spread in the field during harvest. The field was prepared by a rotary tiller to a depth of $0.08 \mathrm{~m}$. Catch crops were sown on the soil surface (24 Aug. 2005, 30 Aug. 2006 and 14 Aug. 2007), which was then harrowed.

Biomass production of catch crops. Dry aboveground biomass production of catch crops, volunteer cereals and weeds was ascertained on patches sized $0.1 \mathrm{~m}^{2}$ (20 Oct. 2005, 1 Nov. 2006 and 1 Nov. 2007) in two pseudo-replicates per experimental plot. Plants were cut near the surface. Samples were dried at $80^{\circ} \mathrm{C}$ and dry matter yield $\left(\mathrm{kg} \mathrm{ha}^{-1}\right)$ was determined. Total above-ground biomass production and dynamics of catch crops growth in the experimental years were presented by Brant et al. (2009). Dry underground biomass production of catch crops (except for T. subterraneum) was determined by using the methodology of root-wash. A soil block (avg. diameter $120 \mathrm{~mm}$, height $200 \mathrm{~mm}$ including above-ground biomass) was sampled from each replication. Dry weight of catch crops above-ground biomass was determined in each sample. Dry weight of underground biomass was weighed after root-wash on sieve with $0.2 \mathrm{~mm}$ mesh size. The following calculation showed the ratio between dry above-ground and underground biomass production values. Production of underground biomass per unit area was calculated from above-ground biomass production values per each replicate and from the ratio between above-ground and underground biomass assessed for each species.

Energy content of catch crops biomass. Energy content of biomass ( $\mathrm{MJ} \mathrm{kg} \mathrm{kg}^{-1}$ ) was established as an arithmetic mean from measurements of four average (i.e. mixed) sample in each treatment. Calorific value in the dry biomass of catch crops, volunteers and weeds was measured by the automatic adiabatic calorimeter system Model IKAC 5000 control (IKA ${ }^{\circledR}$, Werke GmbH \& Co. KG, Germany). The calorific value was calculated according to ISO 1928: 2009, without ash and with no correction for dissolution heat of sulphuric and nitric acids.

Energy balance of catch crops. Energy balance of catch crops was assessed according to methods published by Preininger (1987). Total energy production $\left(\mathrm{GJ} \mathrm{ha}^{-1}\right)$ was calculated from biomass production $\left(\mathrm{kg} \mathrm{ha}^{-1}\right)$ and energy content of biomass $\left(\mathrm{MJ} \mathrm{kg} \mathrm{kg}^{-1}\right)$. Energy inputs included energy of soil preparation, seeds, seeding and harrowing. Energy of seeds was calculated from the seeding rate $\left(\mathrm{kg} \mathrm{ha}^{-1}\right)$ and energy content of seeds $\left(\mathrm{MJ} \mathrm{kg}^{-1}\right)$. Energy gain (difference between energy production and inputs of energy, GJ ha-1) and energy effectiveness (how much energy is produced from one unit of energy input, $\mathrm{GJ} \mathrm{GJ}^{-1}$ ) were calculated.

Statistical analysis. The data were statistically evaluated by using one-way ANOVA in Statistica 9.1 (2010) followed by Tukey post-hoc test ( $\alpha=0.05)$. Dunnett test ( $\alpha=0.05)$ was used to evaluate energy gain of the above-ground biomass of catch crops as compared with the un-seeded control.

\section{Results and discussion}

Energy content of catch crops biomass. Energy production from a certain area of land primarily depends on biomass yield because the content of energy in biomass has smaller variability than the yield (Fuksa et al., 2012). However, determining the content of energy in biomass is important for a precise calculation of energy balances. Calorific value of the above-ground biomass of evaluated catch crops ranged from 15.65 to $20.21 \mathrm{MJ} \mathrm{kg}^{-1}$ (Table 1). These values correspond with values found by Kocourková et al. (2004) in grass biomass (17.00$18.50 \mathrm{MJ} \mathrm{kg}^{-1}$ ), Alluvione et al. (2011) in the straw of winter rape $\left(17.25 \mathrm{MJ} \mathrm{kg}^{-1}\right)$, wheat $18.17\left(\mathrm{MJ} \mathrm{kg}^{-1}\right)$ or maize (18.67 $\left.\mathrm{MJ} \mathrm{kg}^{-1}\right)$ and Fuksa et al. (2012) in grassland biomass (16.89-18.62 $\left.\mathrm{MJ} \mathrm{kg}^{-1}\right)$. Energy content was significantly influenced by year and species. Influence of year on energy content in plant biomass was described by Fuksa et al. (2006) in silage maize. In the assessed catch crops species, the lowest values were found in P. tanacetifolia and species from the Brassicaceae family in all experimental years. The highest values 
Table 1. Calorific value ( $\left.\mathrm{MJ} \mathrm{kg}^{-1}\right)$ in above-ground and underground biomass of studied catch crops in 2005-2007

\begin{tabular}{|c|c|c|c|c|c|c|}
\hline \multirow[t]{2}{*}{ Species } & \multicolumn{3}{|c|}{$\begin{array}{l}\text { Above-ground biomass } \\
\qquad \mathrm{MJ} \mathrm{kg}^{-1}\end{array}$} & \multicolumn{3}{|c|}{$\begin{array}{c}\text { Underground biomass } \\
\mathrm{MJ} \mathrm{kg}^{-1}\end{array}$} \\
\hline & 2005 & 2006 & 2007 & 2005 & 2006 & 2007 \\
\hline Brassica napus & $17.29 \mathrm{~A}$ & $17.48 \mathrm{~A}$ & $18.77 \mathrm{~B}$ & $17.69 \mathrm{~A}$ & $17.81 \mathrm{~A}$ & $18.03 \mathrm{~A}$ \\
\hline Lolium multiflorum & $17.56 \mathrm{~A}$ & $17.49 \mathrm{~A}$ & $19.10 \mathrm{~B}$ & $18.56 \mathrm{~A}$ & $18.54 \mathrm{~A}$ & $18.72 \mathrm{~A}$ \\
\hline Lolium perenne & $16.59 \mathrm{~A}$ & $17.56 \mathrm{~A}$ & $19.11 \mathrm{~B}$ & $18.47 \mathrm{~A}$ & $18.52 \mathrm{~A}$ & $18.58 \mathrm{~A}$ \\
\hline Phacelia tanacetifolia & $15.65 \mathrm{~A}$ & $15.81 \mathrm{~A}$ & $17.78 \mathrm{~B}$ & $18.26 \mathrm{~A}$ & $18.22 \mathrm{~A}$ & $17.90 \mathrm{~A}$ \\
\hline Raphanus sativus & $16.01 \mathrm{~A}$ & $16.44 \mathrm{~A}$ & $18.18 \mathrm{~B}$ & $17.01 \mathrm{~A}$ & $17.05 \mathrm{~A}$ & $18.02 \mathrm{~B}$ \\
\hline Sinapis alba & $17.09 \mathrm{~A}$ & $17.03 \mathrm{~A}$ & $18.46 \mathrm{~B}$ & $18.52 \mathrm{~A}$ & $18.65 \mathrm{~A}$ & $18.47 \mathrm{~A}$ \\
\hline Trifolium incarnatum & $16.98 \mathrm{~A}$ & $18.50 \mathrm{~B}$ & $20.21 \mathrm{C}$ & $19.32 \mathrm{~A}$ & $19.41 \mathrm{~A}$ & $18.77 \mathrm{~A}$ \\
\hline Trifolium subterraneum & $15.73 \mathrm{~A}$ & $18.13 \mathrm{~B}$ & $19.62 \mathrm{C}$ & - & - & - \\
\hline Mean & $16.61 \mathrm{~A}$ & $17.31 \mathrm{~B}$ & $18.90 \mathrm{C}$ & $18.26 \mathrm{~A}$ & $18.28 \mathrm{~A}$ & $18.32 \mathrm{~A}$ \\
\hline P-value & $<0.000$ & $<0.000$ & $<0.000$ & $<0.000$ & $<0.000$ & $<0.000$ \\
\hline$+/-$ Limits & 0.70 & 0.23 & 0.56 & 0.56 & 0.58 & 0.32 \\
\hline
\end{tabular}

Note. Letters express statistical differences among the years within each row for above-ground or underground biomass (Tukey test, $\alpha=0.05$ ); $P$-value and $+/-$ Limits (Tukey test, $\alpha=0.05$ ) express differences among the species within each column for aboveground or underground biomass.

were usually observed in grass species. The reason for lower energy content in the biomass of $S$. alba, R. sativus and P. tanacetifolia could be the species' phenological development to the generative stage. The formation of generative parts might have reduced the energy content in leaves and stalks at this stage. These changes directly depend on changes in the chemical composition of plants, which is related to energy content in plants (Yajing et al., 2007) or leaf/stem ratio and energy content in these different plant parts (Hakl et al., 2010).

Lower variability in energy content among the evaluated catch crops was found in underground biomass (17.01-19.41 MJ kg-1) compared to above-ground biomass. Nevertheless, in accordance with Alluvione et al. (2011), no substantial differences were found between the above-ground and underground biomass. Similarly as in the above-ground biomass, significant differences were found in the energy content of the underground biomass of evaluated species, with higher values measured in the roots of grasses and legumes by contrast to species from the Brassicaceae family and P.tanacetifolia. Except for $R$. sativus, differences among the years were not determined for the energy content of underground biomass. Interaction between the year and the species was not significant. Differences of calorific values among the years were more substantial in above-ground biomass by contrast to underground biomass. Energy contents in the above-ground biomass of volunteers were significantly lower in 2005 and 2006 (17.48 and $17.63 \mathrm{MJ} \mathrm{kg}^{-1}$ ) by contrast to 2007 (19.44 $\left.\mathrm{MJ} \mathrm{kg}^{-1}\right)$ in average of all tested treatments. Energy contents in the above-ground biomass of weeds ranged on average from 17.50 to $17.92 \mathrm{MJ} \mathrm{kg}^{-1}$, respectively in 2005 and 2006. In 2007, the average value amounted to $18.80 \mathrm{MJ} \mathrm{kg}^{-1}$. Measured calorific values of volunteers and weeds were in agreement with values published by Alluvione et al. (2011) in wheat (18.17 $\left.\mathrm{MJ} \mathrm{kg}^{-1}\right)$ and Fuksa et al. (2006) in weed species (16.80-18.21 $\left.\mathrm{MJ} \mathrm{kg}^{-1}\right)$. The highest values of energy content were found in the above-ground biomass of catch crops, volunteers and weeds in 2007. In 2007, the highest production of the above-ground phytomass of catch crops (1478-5336 $\left.\mathrm{kg} \mathrm{ha}^{-1}\right)$ was determined by contrast to 2005 and 2006 (175-1799 kg ha-1 and 104$1808 \mathrm{~kg} \mathrm{ha}^{-1}$, respectively). A detailed description of the growth dynamics of catch crops as related to meteorological conditions in this experiment was published by Brant et al. (2009). Based on meteorological characteristics it was evident that the respective years differed namely in soil moisture conditions. The year 2007 differed considerably from the previous years by being rich in precipitation not only before but also after the sowing date of the catch crops (Brant et al., 2009).

Total energy production of catch crops. Average values of total energy production of the above-ground biomass of individual species of catch crops, volunteers and weeds in 2005-2007 are summarized in Table 2. In the unseeded control, total energy production was $18.19 \mathrm{GJ} \mathrm{ha}^{-1}$ and ranged from 24.74 to $57.02 \mathrm{GJ} \mathrm{ha}^{-1}$ in the stands of studied catch crops on average of years 2005-2007. Catch crops represented $43-94 \%$ of total energy production depending on plant species. The lowest and the highest production in absolute and relative values was found in L. perenne, and in $S$. alba and $R$. sativus, respectively. Talgre et al. (2011) informed about the most effective $S$. alba and $R$. sativus, which produced the highest biomass from 9 tested catch crops in 2008-2010, as well. Marcinkevičienè and Bogužas (2011) also obtained the highest dry mass yield of $S$. alba in the autumn (920 $\left.\mathrm{kg} \mathrm{ha}^{-1}\right)$ while the yields of L. multiflorum and B. napus were lower (59.8\% and $37.0 \%$, respectively), in the sustainable farming system.

Total energy production of catch crops was lower than values ranging from 100 to $300 \mathrm{GJ} \mathrm{ha}^{-1}$, generally reported for common crops grown on arable land in suitable conditions (Fuksa et al., 2006; Boehmel et al., 2008). However, it could be more similar to values published by Moreno et al. (2011) for the semi-arid area (18-26 GJ ha $\left.{ }^{-1}\right)$. Slightly higher values were also observed in permanent grassland. Rösch et al. (2009) claimed the energy production of permanent grassland to range from $66 \mathrm{GJ} \mathrm{ha}^{-1}$ (low-input grassland) to $119 \mathrm{GJ} \mathrm{ha}^{-1}$ (highinput grassland), and Fuksa et al. (2012) published values from 87 to $199 \mathrm{GJ} \mathrm{ha}^{-1}$, depending on the number of cuts and fertilization intensity. 
Table 2. Energy production (GJ ha ${ }^{-1}$ ) of catch crops, volunteers and weeds (average of years 2005-2007)

\begin{tabular}{|c|c|c|c|c|c|c|c|}
\hline \multirow{2}{*}{ Species } & \multicolumn{2}{|c|}{ Catch crop } & \multicolumn{2}{|c|}{ Volunteers } & \multicolumn{2}{|c|}{ Weeds } & \multirow{2}{*}{$\begin{array}{c}\text { Total } \\
\text { GJ ha }^{-1}\end{array}$} \\
\hline & GJ ha-1 & $\%$ & GJ ha-1 & $\%$ & GJ ha-1 & $\%$ & \\
\hline Brassica napus & 17.29 & 70 & 6.38 & 26 & 1.07 & 4 & 24.74 \\
\hline Lolium multiflorum & 17.12 & 63 & 8.90 & 32 & 1.40 & 5 & 27.42 \\
\hline Lolium perenne & 11.09 & 43 & 13.07 & 50 & 1.78 & 7 & 25.94 \\
\hline Phacelia tanacetifolia & 23.41 & 82 & 4.06 & 14 & 1.28 & 4 & 28.75 \\
\hline Raphanus sativus & 38.56 & 91 & 3.36 & 8 & 0.26 & 1 & 42.19 \\
\hline Sinapis alba & 53.75 & 94 & 2.58 & 4 & 1.09 & 2 & 57.02 \\
\hline Trifolium incarnatum & 23.96 & 71 & 8.60 & 25 & 1.22 & 4 & 33.78 \\
\hline Trifolium subterraneum & 22.27 & 68 & 9.23 & 28 & 1.21 & 4 & 32.71 \\
\hline Un-seeded control & - & - & 16.47 & 91 & 1.72 & 9 & 18.19 \\
\hline$P$-value & $<0.000$ & & $<0.000$ & & 0.006 & & $<0.000$ \\
\hline$+/-$ Limits & 8.31 & & 4.51 & & 1.18 & & 9.16 \\
\hline
\end{tabular}

Note. P-value and $+/-$ Limits (Tukey test, $\alpha=0.05$ ) express differences among species within each column.

The proportion of volunteers was negatively related to the biomass production of planted catch crops and ranged from $4 \%$ to $50 \%$. The highest proportion of volunteers was found in treatments with $L$. perenne and the lowest proportion was in the treatment with $S$. alba. The results document the interspecific competition between volunteers and catch crops. As for energy production, a positive effect of the biomass of volunteers can be seen; however, it is necessary to take into account that their production is lower as compared with that of productive catch crop species ( $S$. alba and R. sativus). For species of lower growth in the autumn term of sowing (grasses, legumes and B. napus), the proportion of volunteers ranged from $25 \%$ to $50 \%$ and its contribution to energy production was significant. Volunteers have similar functions as catch crops, e.g., sorption of nutrients. Beaudoin et al. (2005) commented that volunteers can take up as much $\mathrm{N}$ as catch crops.

The lowest energy production was found in weeds. The value was lower than $2 \mathrm{GJ} \mathrm{ha}^{-1}$ in all evaluated treatments. Weeds participated in total energy production by $9 \%$ in the un-seeded control and by $1-7 \%$ in treatments with catch crops. The low proportion of weeds in the production of biomass and energy could be caused by dormancy of seeds in the autumn period and by the competition between the catch crops and volunteers. Our results support a conception that the planting of catch crops is important for weed control, which is in agreement with the suggestions of Rasmussen et al. (2006) about the connection of catch crops management and weed control under conversion to organic farming. The evaluation of energy production in underground biomass of selected catch crops (Fig.) shows the highest value in $R$. sativus $\left(15.58 \mathrm{GJ} \mathrm{ha}^{-1}\right)$, moderate values in other species from the Brassicaceae family, L. multiflorum and T. incarnatum (5.90-8.79 $\left.\mathrm{GJ} \mathrm{ha}^{-1}\right)$, and the significantly lowest values in L. perenne (3.68 $\mathrm{GJ} \mathrm{ha}^{-1}$ ) and P. tanacetifolia $(4.04 \mathrm{GJ}$ $\mathrm{ha}^{-1}$ ). In the majority of catch crops, the ratio of energy accumulated in above-ground biomass to energy in underground biomass ranged from 2.5 to 3.0. There were

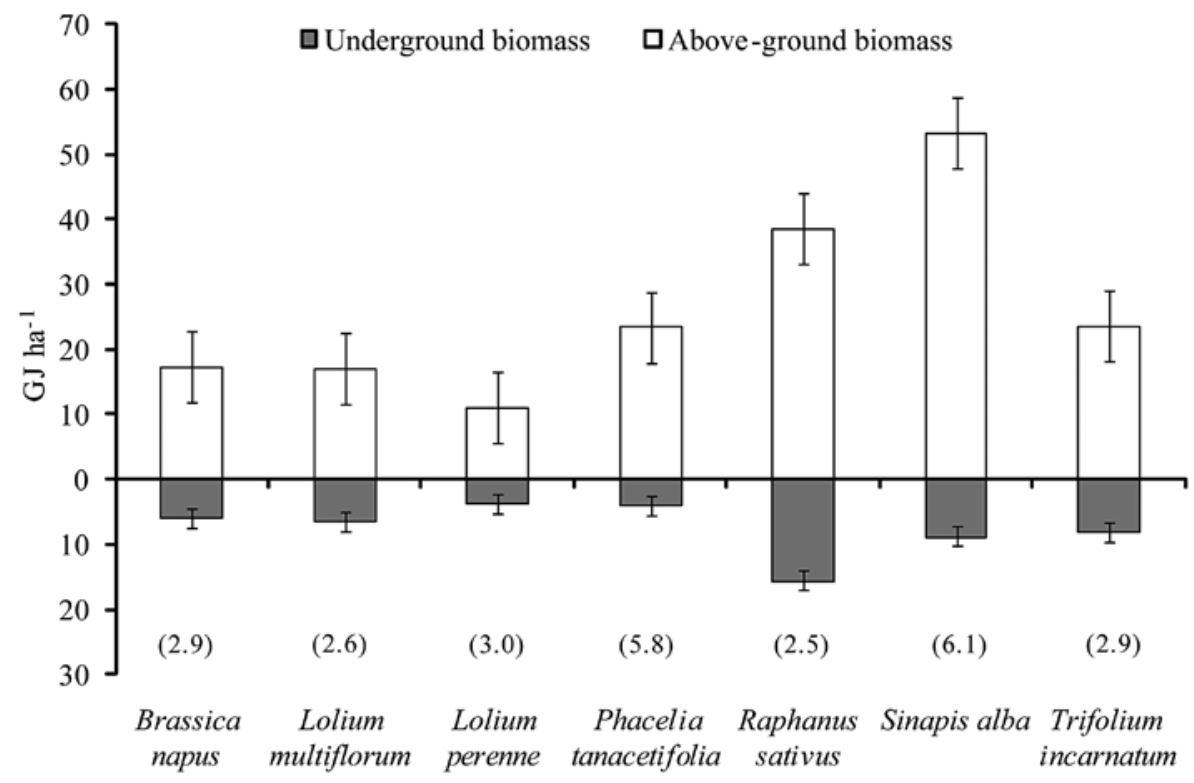

Notes. The ratios of energy accumulated in above-ground to underground biomass are in brackets. Vertical limits indicate standard error of the mean.

Figure. Energy production (GJ ha $\left.{ }^{-1}\right)$ in the above-ground and underground biomass of selected catch crop species, average of years 2005-2007 
only two species ( $S$. alba and P. tanacetifolia), which exceeded the value of 5. Alluvione et al. (2011) reported values around 2-3 for wheat and soybean, too, with values over 5 being found in maize.

Energy balance of catch crops. From the perspective of total energy balances, it is not only the total production of energy that is significant, but it is also important to consider necessary energy inputs. Börjesson (1996) published the energy production of $106 \mathrm{GJ}^{-1}$ in B. napus and $130 \mathrm{GJ} \mathrm{ha}^{-1}$ in T. aestivum (seed/grain and straw) and primary energy inputs amounting to 17.2 and 19.5 GJ ha ${ }^{-1}$, respectively. Fuksa et al. (2012) set out values of energy inputs in permanent grassland within a range from 1.6 to $3.1 \mathrm{GJ} \mathrm{ha}^{-1}$ depending on the number of cuts and from 3.1 to $20.2 \mathrm{GJ} \mathrm{ha}^{-1}$ depending on fertilization intensity. In the intensive cropping system, fertilizers may represent up to $78 \%$ of total energy inputs (Angelini et al., 2005). As compared with these data, significantly lower values of energy inputs $\left(0.76-1.29 \mathrm{GJ} \mathrm{ha}^{-1}\right)$ were determined in the evaluated catch crops, while in the unseeded control this value was only $0.30 \mathrm{GJ} \mathrm{ha}^{-1}$ (Table 3 ). Differences in the total additional energy of catch crop stands resulted from different energy contents in seeds and seeding rates at comparable crop management in all experimental years. However, the observed stands showed also lower energy production as already mentioned in the previous part of discussion.

Table 3. Inputs of additional energy ( $\left.\mathrm{GJ} \mathrm{ha}^{-1}\right)$ calculated in each year (2005-2007) for catch crops and un-seeded control

\begin{tabular}{|c|c|c|c|c|c|c|c|}
\hline \multirow{2}{*}{ Species } & \multicolumn{3}{|c|}{ Seeds } & Soil tillage & Seeding & Harrowing & Total \\
\hline & $\mathrm{MJ} \mathrm{kg}^{-1}$ & $\mathrm{~kg} \mathrm{ha}^{-1}$ & $\mathrm{GJ} \mathrm{ha}^{-1}$ & \multicolumn{4}{|c|}{$\mathrm{GJ} \mathrm{ha}^{-1}$} \\
\hline Brassica napus & 28.69 & 10 & 0.29 & 0.30 & 0.13 & 0.12 & 0.84 \\
\hline Lolium multiflorum & 18.44 & 40 & 0.74 & 0.30 & 0.13 & 0.12 & 1.29 \\
\hline Lolium perenne & 18.70 & 20 & 0.37 & 0.30 & 0.13 & 0.12 & 0.92 \\
\hline Phacelia tanacetifolia & 20.72 & 10 & 0.21 & 0.30 & 0.13 & 0.12 & 0.76 \\
\hline Raphanus sativus & 26.35 & 25 & 0.66 & 0.30 & 0.13 & 0.12 & 1.21 \\
\hline Sinapis alba & 24.17 & 20 & 0.48 & 0.30 & 0.13 & 0.12 & 1.03 \\
\hline Trifolium incarnatum & 20.54 & 25 & 0.51 & 0.30 & 0.13 & 0.12 & 1.06 \\
\hline Trifolium subterraneum & 22.41 & 30 & 0.67 & 0.30 & 0.13 & 0.12 & 1.22 \\
\hline Un-seeded control & - & - & - & 0.30 & - & - & 0.30 \\
\hline
\end{tabular}

On average of three years, all tested catch crops except $B$. napus and $L$. perenne achieved positive energy balance based on energy gain in comparison to un-seeded control; however, significant differences were found among the individual years (Table 4). On average of all treatments, energy gain amounted to $19.28,16.81$ and $57.94 \mathrm{GJ} \mathrm{ha}^{-1}$ in 2005, 2006 and 2007, respectively. Calculated relations among these results correspond with

Table 4. Energy gain $\left(\mathrm{GJ} \mathrm{ha}^{-1}\right)$ of the above-ground biomass of catch crops and un-seeded control in 20052007

\begin{tabular}{lcccc}
\hline \multirow{2}{*}{\multicolumn{1}{c}{ Species }} & \multicolumn{4}{c}{ Energy gain } \\
\cline { 2 - 5 } & 2005 & 2006 & 2007 & $2005-2007$ \\
\hline Brassica napus & 15.47 & 16.91 & 39.30 & 23.90 \\
Lolium multiflorum & 16.20 & $3.98^{*}$ & $58.12^{*}$ & $26.13^{*}$ \\
Lolium perenne & 15.67 & 8.39 & $51.01^{*}$ & 25.02 \\
Phacelia tanacetifolia & $19.18^{*}$ & 21.09 & 43.70 & $27.99^{*}$ \\
Raphanus sativus & $28.53^{*}$ & 16.50 & $77.89^{*}$ & $40.98^{*}$ \\
Sinapis alba & $35.45^{*}$ & $31.96^{*}$ & $100.57^{*}$ & $55.99^{*}$ \\
Trifolium incarnatum & 15.95 & 16.15 & $66.07^{*}$ & $32.72^{*}$ \\
Trifolium subterraneum & $18.26^{*}$ & 19.23 & $56.98^{*}$ & $31.49^{*}$ \\
\hline Un-seeded control & 8.84 & 17.11 & 27.73 & 17.89 \\
\hline \multicolumn{1}{c}{ Mean } & 19.28 & 16.81 & 57.94 & 31.34 \\
\hline
\end{tabular}

* - represents statistical differences as compared with the unseeded control (Dunnett test, $\alpha=0.05$ ) the sum of precipitation recorded in the vegetation period of catch crops. A detailed description of precipitation was published by Brant et al. (2009). In 2005 and 2006, the sum of precipitation was 36.2 and $36.4 \mathrm{~mm}$, respectively, from the sowing date of catch crops to the date of biomass sampling. In 2007, the sum of precipitation during the same period was $129.6 \mathrm{~mm}$. In 2007, positive energy balance was found in a majority of tested plant species in optimal moisture conditions. The only species that achieved significantly positive energy balance in all three years was $S$. alba. Effectiveness of the utilization of global radiation and other vegetative factors could play an important role for EUE of individual catch crop species, too (Brant et al., 2011). Positive energy balance of catch crops depended also on the production of un-seeded control in the individual years. Our results show the importance of weather course and year on the utilization of identical energy inputs each year. In spite of relatively low energy inputs in catch crops, a significantly positive balance was found each year only in some species. This is in accordance with the results of Moreno et al. (2011) on reduced effectiveness of energy inputs under arid and semi-arid conditions. In terms of catch crop yield in humid conditions, Masilionytė and Maikštenienè (2011) determined the weak relationship between biomass production of catch crops and amount of precipitation in range from 159.8 to $256.8 \mathrm{~mm}$ during August-October.

Influence of the year is obvious in the evaluation of energy effectiveness, as well (Table 5). These values are directly derived from the values of energy production 
and input; therefore, statistical significance was not calculated. The highest value was found in the un-seeded control (60.64 $\mathrm{GJ} \mathrm{GJ}^{-1}$ ); the evaluated catch crops ranged from 21.27 to $55.19 \mathrm{GJ} \mathrm{GJ}^{-1}$ on the average of years 2005-2007. Higher energy effectiveness was determined only in $S$. alba by contrast to the un-seeded control in 2005 and 2007.

Table 5. Energy effectiveness (GJ GJ ${ }^{-1}$ ) of the aboveground biomass of evaluated catch crops and un-seeded control in 2005-2007

\begin{tabular}{lcccc}
\hline \multirow{2}{*}{\multicolumn{1}{c}{ Species }} & \multicolumn{5}{c}{ Gnergy effectiveness } \\
\cline { 2 - 6 } & 2005 & 2006 & 2007 & $2005-2007$ \\
\hline Brassica napus & 19.49 & 21.21 & 47.96 & 29.55 \\
Lolium multiflorum & 13.58 & 4.09 & 46.14 & 21.27 \\
Lolium perenne & 17.96 & 10.08 & 56.21 & 28.08 \\
Phacelia tanacetifolia & 26.33 & 28.85 & 58.72 & 37.97 \\
Raphanus sativus & 24.60 & 14.65 & 65.43 & 34.89 \\
Sinapis alba & 35.31 & 31.93 & 98.33 & 55.19 \\
Trifolium incarnatum & 16.00 & 16.18 & 63.12 & 31.77 \\
Trifolium subterraneum & 15.94 & 16.73 & 47.61 & 26.76 \\
\hline Un-seeded control & 30.47 & 58.03 & 93.43 & 60.64 \\
\hline \multicolumn{1}{c}{ Mean } & 22.19 & 22.42 & 64.11 & 36.24 \\
\hline
\end{tabular}

These observed values of catch crops are higher than those published by Hülsbergen et al. (2001) for main crops grown on arable land: for potatoes $\left(4.3 \mathrm{GJ} \mathrm{GJ}^{-1}\right)$, winter barley $\left(9.4 \mathrm{GJ}_{\mathrm{GJ}}{ }^{-1}\right)$, spring barley $\left(9.9 \mathrm{GJ} \mathrm{GJ}^{-1}\right)$, winter wheat (14.4 GJ GJ-1 $)$ and sugar beet (11.1 GJ GJ-1). Generally, EUE decreases with the higher intensity of management (Alluvione et al., 2011). Fuksa et al. (2012) found this parameter decreasing from 55.19 to $9.86 \mathrm{GJ} \mathrm{GJ}^{-1}$ with the increasing number of cuts and fertilization intensity in permanent grassland. Moreno et al. (2011) determined the system of organic farming (5.36 GJGJ-1) about 2.3 times more energy efficient than the conventional or conservation systems (2.35 and 2.38 GJ GJ ${ }^{-1}$, respectively) under the semiarid conditions over a 15-year period. The influence of year on energy gain and energy effectiveness objectively shows an important effect of weather course on the annual utilization of identical energy inputs to the system of catch crops management.

\section{Conclusions}

1. Energy content of the above-ground biomass of catch crops was significantly influenced by the species and year. The lowest values were found in Phacelia tanacetifolia and in species from the Brassicaceae family. The highest values were usually recorded in grass species. Lower variability in energy content among the evaluated catch crops was found in underground biomass compared to above-ground biomass.

2. Total energy production and balance of a catch crop stand result from an interaction among the used catch crop species, presence of volunteers and weeds in relation to weather conditions in the particular year. The lowest and highest absolute and relative values of energy production were found in Lolium perenne, and in Sinapis alba and Raphanus sativus, respectively. As a result of very low energy inputs to the growing system, catch crops showed very high values of energy effectiveness.

3. Selection of suitable catch crop species plays a very important role in areas with limited precipitation. Almost all tested species reached positive energy balance in the year with favourable conditions; however, this significantly positive balance across all evaluated years was reached in stands with $S$. alba. As for the other evaluated parameters, the lowest value of additional energy was found in Phacelia tanacetifolia and the additional intensive accumulation of energy in underground biomass was recorded in $R$. sativus.

\section{Acknowledgements}

Supported by the Ministry of Education, Youth and Sports of the Czech Republic, "S" Grant and Projects QF 4167. Authors are thankful to Daniela Kocourková for her useful help.

Received 11032013

Accepted 09092013

\section{References}

Alluvione F., Moretti B., Sacco D., Grignani C. 2011. EUE (energy use efficiency) of cropping systems for a sustainable agriculture. Energy, 36 (7): 4468-4481 http://dx.doi.org/10.1016/j.energy.2011.03.075

Angelini L. G., Ceccarini L., Bonari E. 2005. Biomass yield and energy balance of giant reed (Arundo donax L.) cropped in central Italy as related to different management practices. European Journal of Agronomy, 22 (4): 375-389 http://dx.doi.org/10.1016/j.eja.2004.05.004

Beaudoin N., Saad J. K., van Laethem C., Machet J. M., Maucorps J., Mary B. 2005. Nitrate leaching in intensive agriculture in Northern France: effect of farming practices, soils and crop rotations. Agriculture, Ecosystems and Environment, 111 (1-4): 292-310

http://dx.doi.org/10.1016/j.agee.2005.06.006

Boehmel C., Lewandowski I., Claupein W. 2008. Comparing annual and perennial energy cropping systems with different management intensities. Agricultural Systems, 96 (1-3): 224-236 http://dx.doi.org/10.1016/j.agsy.2007.08.004

Börjesson P. I. I. 1996. Energy analysis of biomass production and transportation. Biomass and Bioenergy, 11 (4): 305318 http://dx.doi.org/10.1016/0961-9534(96)00024-4

Brant V., Neckáŕ K., Pivec J., Duchoslav M., Holec J., Fuksa P., Venclová V. 2009. Competition of some summer catch crops and volunteer cereals in the areas with limited precipitation. Plant, Soil and Environment, 55 (1): 17-24

Brant V., Pivec J., Fuksa P., Neckář K., Kocourková D., Venclová V. 2011. Biomass and energy production of catch crops in areas with deficiency of precipitation during summer period in central Bohemia. Biomass and Bioenergy, 35 (3): 1286-1294 http://dx.doi.org/10.1016/j.biombioe.2010.12.034 
Fuksa P., Kocourková D., Hakl J., Kalista J. 2006. Influence of weed infestation on the calorific value and chemical composition of maize (Zea mays L.). Journal of Plant Diseases and Protection, XX (spec. iss.): 823-830

Fuksa P., Hakl J., Hrevušová Z., Šantrůček J., Gerndtová I., Habart J. 2012. Utilization of permanent grassland for biogas production. Sahin A. S. (ed.). Modeling and optimization of renewable energy systems. Rijeka, Croatia, p. $171-196$

Hakl J., Mášková K., Fuksa P., Šantrůček J. 2010. The changes in gross energy content in lucerne leaves and stems in the first cut. $14^{\text {th }}$ international symposium Forage Conservation. Brno, Czech Republic, p. 130-133

Hülsbergen K.-J., Feil B., Biermann S., Rathke G.-W., Kalk W. D., Diepenbrock W. 2001. A method of energy balancing in crop production and its application in a long-term fertilizer trial. Agriculture, Ecosystems and Environment, 86 (3): 303-321 http://dx.doi.org/10.1016/S0167-8809(00)00286-3

ISO 1928: 2009. Solid mineral fuels - Determination of gross calorific value by the bomb calorimetric method, and calculation of net calorific value, $70 \mathrm{p}$.

Joelsson A., Kyllmar K. 2002. Implementation of best management practices in agriculture: modelling and monitoring of impacts on nitrogen leaching. Water Science and Technology, 45 (9): 43-50

Kocourková D., Hak1 J., Fuksa P., Mrkvička J. 2004. Festuca arundinacea Schr. and Bromus marginatus Nees et Stend. as possible energy crops in the Czech Republic. Grassland Science in Europe, 9: 852-854

Marcinkevičienè A., Bogužas V. 2011. The effect of meteorological factors on the productivity of catch crops in sustainable and organic farming systems. ZemdirbysteAgriculture, 98 (3): 245-250

Masilionytė L., Maikštenienè S. 2011. The effect of agronomic and meteorological factors on the yield of main and catch crops. Zemdirbyste-Agriculture, 98 (3): 235-244

Moravec D., Votýpka J. 2003. Regionalised modelling. Prague, Czech Republic, 197 p.

Moreno M. M., Lacasta C., Meco R., Moreno C. 2011. Rainfed crop energy balance of different farming systems and crop rotations in a semi-arid environment: results of a long term trial. Soil and Tillage Research, 114 (1): 18-27 http://dx.doi.org/10.1016/j.still.2011.03.006

Poggio S. 2005. Structure of weed communities occurring in monoculture and intercropping of field pea and barley. Agriculture, Ecosystems and Environment, 109 (1-2): 48-58 http://dx.doi.org/10.1016/j.agee.2005.02.019

Prade T., Svensson S.-E., Andersson A., Mattsson J. E. 2011. Biomass and energy yield of industrial hemp grown for biogas and solid fuel. Biomass and Bioenergy, 35 (7): 3040 3049 http://dx.doi.org/10.1016/j.biombioe.2011.04.006

Preininger M. 1987. Energy evaluation of production process in plant production. Prague, Czech Republic, 29 p. (in Czech)

Rasmussen I. A., Askegaard M., Olesen J. E., Kristensen K. 2006. Effects on weeds of management in newly converted organic crop rotations in Denmark. Agriculture, Ecosystems and Environment, 113 (1-4): 184-195 http://dx.doi.org/10.1016/j.agee.2005.09.007
Rösch C., Skarka J., Raab K., Stelzer V. 2009. Energy production from grassland - assessing the sustainability of different process chains under German conditions. Biomass and Bioenergy, 33 (4): 689-700 http://dx.doi.org/10.1016/j.biombioe.2008.10.008

Statistica, version 9.1. 2010. StatSoft Inc., Tulsa, USA

Talgre L., Lauringson E., Makke A., Lauk R. 2011. Biomass production and nutrient binding of catch crops. Zemdirbyste-Agriculture, 98 (3): 251-258

Venturi P., Venturi G. 2003. Analysis of energy comparison for crops in European agricultural systems. Biomass and Bioenergy, 25 (3): 235-255 http://dx.doi.org/10.1016/S0961-9534(03)00015-1

Yajing B., Zhenghai L., Xingguo H., Guodong H., Yankai Z. 2007. Caloric content of plant species and its role in a Leymus chinensis steppe community of Inner Mongolia, China. Acta Ecologica Sinica, 27 (11): 4443-4451 http://dx.doi.org/10.1016/S1872-2032(08)60002-5

Zentner R. P., Basnyat P., Brandt S. A., Thomas A. G., Ulrich D., Cambell C. A., Nagy C. N., Frick B., Lemke R., Malhi S. S., Fernandez M. R. 2011. Effects of input management and crop diversity on non-renewable energy use efficiency of cropping systems in the Canadian Prairie. European Journal of Agronomy, 34 (2): 113-123 http://dx.doi.org/10.1016/j.eja.2010.11.004 
ISSN 1392-3196 / e-ISSN 2335-8947

Zemdirbyste-Agriculture, vol. 100, No. 4 (2013), p. 355-362

DOI 10.13080/z-a.2013.100.045

\title{
Tarpinių augalų produkcijos energinis balansas
}

\author{
P. Fuksa, J. Hakl, V. Brant
}

Prahos gyvybės mokslų universitetas, Čekijos Respublika

\begin{abstract}
Santrauka
Straipsnio tikslas - ịvertinti iš tarpiniu pasèliu gaunamos energijos kiekị ir efektyvumą regionuose, kur iškrinta ribotas kiekis kritulių. 2005-2007 m. tirti aštuonių rūšiu augalai: Brassica napus, Lolium multiflorum, Lolium perenne, Phacelia tanacetifolia, Raphanus sativus var. oleiformis, Sinapis alba, Trifolium incarnatum, Trifolium subterraneum ir nesètas kontrolinis variantas. Nustatyta tarpinių pasèlių, iš sẻklų pabirų išaugusių augalų ir piktžolių biomasės energijos kiekis ( $\mathrm{MJ} \mathrm{kg}{ }^{-1}$ ) bei energijos gamyba $\left(\mathrm{GJ} \mathrm{ha}^{-1}\right)$ ir apskaičiuotas energijos balansas (sąnaudos, prieaugis, efektyvumas). Tarpinių augalų antžeminès biomasės energijos kiekiui $\left(15,65-20,21 \mathrm{MJ} \mathrm{kg}^{-1}\right)$ esminès $(P<0,05)$ ịtakos turèjo augalo rūšis ir metai. $2005-2007 \mathrm{~m}$. bendros energijos produkcijos gauta vidutiniškai $18,19 \mathrm{GJ} \mathrm{ha}^{-1}$ nesėtame kontroliniame variante (piktžolès ir augalai, išaugę iš sèklų pabirų), o pasèliuose su tirtais tarpiniais augalais ji svyravo nuo 24,74 iki 57,02 $\mathrm{GJ} \mathrm{ha}^{-1}$. Tarpiniai augalai sudare $43-94 \%$ bendros energijos produkcijos, priklausomai nuo augalų rūšies. Palyginus su kontroliniu variantu, tirtų tarpinių augalų teigiamam energijos balanso prieaugiui turẻjo ịtakos metų sąlygos, ypač dirvožemio drègnis. Visais trimis tyrimų metais teigiamas energijos balansas buvo tik $S$. alba pasėliuose. Mažiausia pridètinės energijos vertè buvo P. tanacetifolia pasèlių, o požeminèje masèje daugiausia energijos sukaupè $R$. sativus.
\end{abstract}

Reikšminiai žodžiai: augalai, išaugę iš sẻklų pabirų, energijos gamyba, piktžolès, tarpinis augalas, šiluminè vertè. 